\title{
Combined Effect of UV-C and Ozone on Bioactive Compounds and Microbiological Quality of Fresh-Cut Rocket Leaves
}

\author{
Diego R. Gutiérrez ${ }^{1,2}$, Silvia Del C. Rodríguez ${ }^{1,2, *}$ \\ ${ }^{1}$ Centro de Investigaciones en Biofisica Aplicada y Alimentos (CIBAAL). CONICET-Universidad Nacional de Santiago del Estero \\ (UNSE). RN 9, Km 1125. El Zanjón. (CP 4206)-Santiago del Estero. Argentina \\ ${ }^{2}$ Instituto de Ciencia y Tecnología de Alimentos (ICyTA-FAyA-UNSE). Belgrano (S) No 1912-Santiago del Estero, Argentina \\ *Corresponding author: silviadepece@hotmail.com
}

Received September 10, 2018; Revised October 30, 2018; Accepted April 01, 2019

\begin{abstract}
The separate application of UV-C $\left(25 \mathrm{~kJ} / \mathrm{m}^{2}, 380 \mathrm{~s}\right)$ and $\mathrm{O}_{3}$ gaseous $(2.5 \mathrm{mg} / \mathrm{L}$ for $10 \mathrm{~min})$ treatments and of their combination $\left(25 \mathrm{~kJ} / \mathrm{m}^{2} \mathrm{UV}-\mathrm{C}\right.$ with $\left.2.5 \mathrm{mg} / \mathrm{L} \mathrm{O} \mathrm{O}_{3}\right)$ were studied to evaluate the effect of combined treatments of UV-C and $\mathrm{O}_{3}$ on microbial counts, bioactive profile and sensory changes of fresh-cut rocket leaves throughout shelf life to determine whether these treatment have additive or synergistic. The separate application of UV-C and $\mathrm{O}_{3}$ and of their combination UV-C $+\mathrm{O}_{3}$ did not affect the sensorial quality, total chlorophyll contents, phenolic compound nor antioxidant capacity of fresh-cut rocket leaves. However, these treatments controlled better the growth of epiphytic microbes than untreated samples. The UV-C treatment had better effect at reducing microorganisms present and not significant differences were found as to the combined treatment. Therefore, applying the combined treatment UV-C $+\mathrm{O}_{3}$ had neither synergistic nor additive effect in the extension of the fresh-cut rocket leaves shelf life.
\end{abstract}

Keywords: UV-C, ozone, synergism, bioactive compounds, quality, rocket

Cite This Article: Diego R. Gutiérrez, and Silvia Del C. Rodríguez, "Combined Effect of UV-C and Ozone on Bioactive Compounds and Microbiological Quality of Fresh-Cut Rocket Leaves." American Journal of Food Science and Technology, vol. 7, no. 3 (2019): 71-78. doi: 10.12691/ajfst-7-3-1.

\section{Introduction}

In recent years, the consumption of fresh-cut vegetables has increased enormously due to its freshness and its ease of use, reducing the time of preparation of meals $[1,2]$. In addition, these products contain different phytochemicals and antioxidants that prevent some diseases [3].

The rocket (Eruca sativa Mill.), belongs to the Brassicaceae family and originated from the Mediterranean region. Its leaves and stems are consumed in salads and are distinguished by their unique and slightly spicy flavor [4]. Brassicaceae vegetables are beneficial for health because they contain many biologically active molecules such as sulfur and nitrogen compounds, which make the rocket more convenient for a healthy eating [5].

During the preparation of fresh-cut vegetables, are applied unit operations such as washing, peeling and cutting, what cause degradative changes limiting their shelf life $[1,6]$. These physical injuries during processing stimulate respiratory intensity, ethylene production and loss of nutrients from the cells, so fresh-cut vegetables those more susceptible to browning and microbial contaminations compared to whole products [2]. Therefore, it is necessary to find postharvest technologies to improve and prolong the conservation of these products.

In recent times, treatments with UV-C radiation emerged as an alternative for chemical disinfection and reduction of vegetative microorganisms in food [1]. It has been demonstrated that UV-C radiation can be applied in fresh products for the disinfection and reduction of microbial development without affecting its quality $[1,7,8]$.

In this way, studies carried out by several authors have shown that UV-C application can maintain quality and extended the shelf life of various vegetables such as minimally processed broccoli, fresh-cut green pepper, fresh-cut paprika, fresh-cut Chokanan mango and Josephine pineapple $[9,10,11]$. In addition, the advantages of these treatments with UV-C radiation is that they use low cost equipment, easy to use and do not require large safety equipment [1].

Besides, other authors reported that treatments with low doses of UV-C of 0.25 to $8.0 \mathrm{~kJ} / \mathrm{m}^{2}$, induce an activation of the plant of primary and secondary compounds that control the reactive oxygen species (ROS), that may can promote the improvement the nutritional quality and health benefits $[12,13,14]$. For example, several authors reported that treatments with UV-C caused the synthesis of phenolic compounds in different vegetables such as tomato [15,16], peeled garlic [17] and mango Chokanan and pineapple Josephine [11]. 
Currently, ozone $\left(\mathrm{O}_{3}\right)$ is another postharvest technology that has a high interest to be used as a disinfectant agent against human pathogens [18]. The food industries use ozone as a disinfectant agent (approved by US-FDA [19]) due to its rapid decomposition to oxygen, which reduces concerns about the toxic waste it could cause [20]. The antimicrobial action of ozone can be due to the oxidation of the cellular vital components which causes the inhibition of the microbial development or indirectly through the defense mechanisms as a response of the plants [21]. Several studies have been carried out on the antimicrobial capacity of ozone and its effects on the quality of different products such as papaya [18], lettuce and spinach [20], fresh-cut melon [22] and fresh-cut apple [23]. In addition, other study has shown that gaseous ozone can have a positive effect on changes in the content of antioxidant components, e.g., flavonoids and other phenolic compounds [24,25].

So, postharvest treatments with $\mathrm{UV}-\mathrm{C}$ and $\mathrm{O}_{3}$ could be a technological alternative for the decontamination of the surface of fresh-cut rocket leaves, maintaining their general quality [26]. On the other hand, Martínez-Hernández et al. [27] reported that the combined application of sanitizing treatments could have a synergistic effect that allows a greater microbial reduction in the products. However, up to date, no studies have been reported on the combined effect of postharvest technologies with UV-C and $\mathrm{O}_{3}$ on the quality of fresh-cut rocket leaves.

Therefore, the objective of this work was to investigate the effect of combined treatments of UV-C and $\mathrm{O}_{3}$ on microbial counts, bioactive profile and sensory changes of fresh-cut rocket leaves throughout shelf life to determine whether these treatment have additive or synergistic.

\section{Materials and Methods}

\subsection{Plant Material and Chemicals}

The rocket was obtained from a local farmer in Santiago del Estero, Argentina. Upon harvest, leaves without stems were transported to laboratory and stored at $5^{\circ} \mathrm{C}$ in a clean room. The next day, leaves at $5-6^{\circ} \mathrm{C}$ were minimally processed in a disinfected area at $16^{\circ} \mathrm{C}$. The chemicals were obtained from Merck Química (Buenos Aires, Argentina).

\subsection{Sample Preparation, Treatments and Storage Conditions}

In the experiments, defect-free rocket leaves were used, i.e. yellowish, physically damaged, dehydrated or cut leaves were discarded. Upon selection, they were washed with tap water $\left(5^{\circ} \mathrm{C}\right)$ for $1 \mathrm{~min}$, drained on a stainless-steel mesh, sliced in portions of about $20 \mathrm{~mm}$ using a stainless-steel knife and eventually re-washed for $2 \mathrm{~min}$ at $5^{\circ} \mathrm{C}$. The water remaining over the cut leaves was centrifuged with a manual centrifuge and the dried leaves submitted to the separate sanitizing treatments with UV-C and $\mathrm{O}_{3}$ and that with both combined. The following treatments were applied: $\mathrm{T}_{1}$ (control): $0 ; \mathrm{T}_{2}\left(\mathrm{O}_{3}\right): 2.5 \mathrm{mg} / \mathrm{L}$ for $10 \mathrm{~min} \mathrm{O}_{3} ; \mathrm{T}_{3}(\mathrm{UV}-\mathrm{C}): 25 \mathrm{~kJ} / \mathrm{m}^{2} \mathrm{UV}-\mathrm{C}(380 \mathrm{~s})$ of UV-C dose (the exposure time was calculated according to the radiation intensity); $\mathrm{T}_{4}\left(\mathrm{UV}-\mathrm{C}+\mathrm{O}_{3}\right)$ : combination of $\mathrm{T}_{2}+\mathrm{T}_{3}$. Both the UV-C doses and $\mathrm{O}_{3}$ gaseous concentrations were selected in accordance with the results of preliminary experiments carried out by the authors with minimally processed rocket leaves [26,28]. UV-C treatment was applied in a reflective stainless-steel chamber equipped with 6 unfiltered germicidal lamps (254.7 nm, TUV 36W/G36, Philips, Amsterdam, The Netherlands), on its topside and 6 at its bottom. A constant light source of $254 \mathrm{~nm}$ was used (intensity of radiation $0,066 \mathrm{~kW}$ ) and applied upon the samples for different exposure times according to the test. The UV-C radiation dose was measured with a digital radiometer (Cole-Parmer Instrument Company, Vernon Hill, IL). For $\mathrm{O}_{3}$ treatment was used a $1 \mathrm{~g} / \mathrm{h}$ ozone generator (Bio3 Ozone Generator, TDZ-1 model, Uruguay). The ozone concentration within the chamber was recorded via an ozone analyzer (Gas Alert Extreme $\mathrm{O}_{3}$-BW Technology, Honeywell, Canada). These UV-C and $\mathrm{O}_{3}$ equipment's used in this work is fully described in Gutiérrez et al. [26].

In every treatment, $70 \mathrm{~g}$ of cut leaves were placed in polypropylene (PP) trays of $600 \mathrm{~mL}$ capacity which were thermally sealed at the top with a bi-oriented polypropylene film of $35 \mu \mathrm{m}$ in thickness to generate a passive modified atmosphere packaging (MAP). The $\mathrm{O}_{2}$ and $\mathrm{CO}_{2}$ transmission rates at $20^{\circ} \mathrm{C}$ and $90 \% \mathrm{RH}$ was $5,000 \mathrm{~mL} / \mathrm{m}^{2} / \mathrm{d} / \mathrm{atm}$ and $18,000 \mathrm{~mL} / \mathrm{m}^{2} / \mathrm{d} / \mathrm{atm}$, respectively, and the water vapor transmission rate was $110 \mathrm{~g} / \mathrm{m}^{2} / \mathrm{d} / \mathrm{atm}$ (data provided by INTI, Argentina). All the trays were stored at $5^{\circ} \mathrm{C}$. For each treatment and sampling time, three replicates were prepared. Analyzes of the different parameters were performed on days $1,4,8$ and 12 of shelf-life.

\subsection{Respiration Rate and Gas Composition within Packages}

A closed system was used to determine the respiratory rate (RR) of the cut rocket. Samples of $30 \mathrm{~g}$ were placed for triplicate in $750 \mathrm{~mL}$ glass bottles at $5^{\circ} \mathrm{C}$. After closing the bottles, the increase in $\mathrm{CO}_{2}$ was monitored for $1 \mathrm{~h}$. With a gas-tight syringe, $1 \mathrm{~mL}$ of sample was removed from the headspace gases and analyzed in a gas chromatograph (GC SRI 8610C, USA). The GC was equipped with a thermal conductivity detector $\left(150^{\circ} \mathrm{C}\right)$, oven $\left(80^{\circ} \mathrm{C}\right)$, injector $\left(150^{\circ} \mathrm{C}\right)$ and Poropack-Q $80 / 100$ column. The carrier gas was He $(20 \mathrm{~mL} / \mathrm{min})$. For each treatment and evaluation period, three repetitions were performed.

The partial pressures of the gases $\left(\mathrm{O}_{2}\right.$ and $\left.\mathrm{CO}_{2}\right)$ were recorded inside the packages on the day of processing and on days $1,4,8$ and 12 of storage at $5^{\circ} \mathrm{C}$, for which a gas analyzer (PBI Dansensor, Check-Point, Ringsted, Denmark) was used. For each treatment and evaluation period, three repetitions were determined.

\subsection{Sensory Evaluation}

An eight-membered trained panel (aged between 24-64) performed the sensory evaluation of the samples on days 1, 4, 8 and 12 of storage using a 9-point scale for overall visual quality and decay as follows: $9=$ excellent, 7 = good, $5=$ acceptable (limit of acceptability), $3=$ poor and $1=$ extremely poor. Color and odor were evaluated using a 5-point scale, that is, $5=$ full characteristic of the product, 3 = acceptable (limit of acceptability) and $1=$ no characteristic, as indicated by Gutiérrez et al. [26]. 


\subsection{Microbiological Analysis}

To determine the various microbial groups (mesophilic, psychrophilic, enterobacteria and yeasts and molds), a 10 $\mathrm{g}$ sample was placed under sterile conditions in a stomacher bag. Upon the addition of $90 \mathrm{~mL}$ of sterile buffered peptone, the mixture was homogenized in a masticator (Bioamerican Science, Argentina) for $2 \mathrm{~min}$ and a diluted aliquot was prepared in an $0.1 \%$ isotonic peptone water as needed. For the aerobic mesophilic count, $100 \mu \mathrm{L}$ of the diluted sample was spread on a plate count agar (PCA), incubated at $37^{\circ} \mathrm{C}$ for 2 days and then at $5^{\circ} \mathrm{C}$ for 7 days for counting aerobic psychrophilic. For the counting of enterobacteria, $100 \mu \mathrm{L}$ of the diluted sample was spread on an eosin methylene blue agar (EMB) and incubated at $37^{\circ} \mathrm{C}$ for 2 days; and for the yeast and mould counts, $100 \mu \mathrm{L}$ of the diluted sample was spread on potato dextrose (PD) with addition of $2 \mathrm{~mL} / \mathrm{L}$ of lactic acid incubated at $27^{\circ} \mathrm{C}$ for 7 days. The analyses for each replicate were repeated three times and the results expressed on fresh weight basis as $\log \mathrm{CFU} / \mathrm{g}$.

\subsection{Chlorophyll and Carotenoid Content}

Both chlorophyll and carotenoids were extracted in accordance with Gutiérrez et al. [29]. To perform the chemical determinations, samples $(10 \mathrm{~g})$ of each treatment per replicate were frozen at $-80^{\circ} \mathrm{C}$ and stored until the measurements were taken on the different days of evaluation. An $0.4 \mathrm{~g}$ frozen rocket sample was triturated using $15 \mathrm{~mL}$ of an acetone:water $(80: 20$, v: v) solution. The samples were then centrifuged for $15 \mathrm{~min}$ at 5,000 $\mathrm{x} \mathrm{g}$ at $4^{\circ} \mathrm{C}$. Their absorbance was measured at $663.2,646.8$ and $470 \mathrm{~nm}$ using an UV-visible spectrophotometer (JASCO, model V-630, Japan). To determine the total chlorophyll and carotenoid contents, equations described by Lichtenthaler [30] and the results expressed in mg per $100 \mathrm{~g}$ of fresh weight (fw) were used.

\subsection{Total Phenolic Compounds}

The phenolic compounds were extracted according to the procedure described by Gutiérrez et al. [29]. The $4 \mathrm{~g}$ frozen rocket samples were homogenized with $20 \mathrm{~mL}$ of methanol and centrifuged at $6,000 \mathrm{x} \mathrm{g}$ at $4^{\circ} \mathrm{C}$ for $15 \mathrm{~min}$ being the supernatant used as an extract of each sample. The total phenolic contents were determined using the Folin-Ciocalteau reagent as described by Singleton [31]. The absorbance of each sample was measured after an hour of incubation at $25^{\circ} \mathrm{C}$ in darkness using an UV-visible spectrophotometer (JASCO V-630) at $765 \mathrm{~nm}$. The results were expressed as chlorogenic acid equivalents (ChAEq) in $\mathrm{mg} / \mathrm{g}$ fw. All the measurements were made in triplicates.

\subsection{Antioxidant Capacity}

The antioxidant capacity of the samples was assessed through the method described by Brand-Williams et al. [32], namely 1,1-diphenyl-2-picrylhydrazyl (DPPH) free radical-scavenging. A $150 \mu \mathrm{L}$ aliquot of the sample extract described above was added to $2,850 \mu \mathrm{L}$ of $0.1 \mathrm{mM}$ DPPH solution dissolved in ethanol. After one hour in the dark, the absorbance of the sample at $515 \mathrm{~nm}$ was measured using a spectrophotometer (JASCO V-630, UV-vis). A calibration curve was depicted using the Trolox solution. The results were expressed as Trolox equivalents (TE) in $\mathrm{mg} / \mathrm{g} \mathrm{fw}$. All the measures were made in triplicate.

\subsection{Statistical Analysis}

The data were statistically analyzed through ANOVA using the 2011 Infostat software (UNC-Argentina). All the experiments were conducted in triplicate. The data were presented as means \pm SD. The significant differences were compared against the least significant difference (LSD) at a significance level of 0.05 .

\section{Results and Discussion}

\subsection{Respiration Rate and Gas Composition within Packages}

After the initial stress induced by the minimal processing, the RR of the control samples was $457 \mathrm{~mL} \mathrm{CO} 2 / \mathrm{kg} / \mathrm{h}$ at $5^{\circ} \mathrm{C}$ Figure 1 . Initially, the $\mathrm{O}_{3}$ treatment inhibited significantly the RR in respect of the control and the UV-C and UV$\mathrm{C}+\mathrm{O}_{3}$ treatments. No significant difference was found between UV-C and UV-C $+\mathrm{O}_{3}$ treated samples and control.

Then, the RR of all the treated rocket leaves samples decreased significantly $(\mathrm{P}<0.05)$ along the 12 day storage at $5^{\circ} \mathrm{C}$. The UV-C treated samples registered $\mathrm{RR}$ similar to the combined treatment with UV-C $+\mathrm{O}_{3}$ for the first four days, showing values higher that the control and the $\mathrm{O}_{3}$ treated samples. However, at the end of storage all the treatments presented similar RR values without significant differences.

The increase in the RR of the fresh-cut rocket leaves produced by the UV-C radiation agrees with studies by Martínez-Hernández et al. [27] on broccoli treated with $1.5,4.5,9.0$ and $15.0 \mathrm{~kJ} / \mathrm{m}^{2} \mathrm{UV}-\mathrm{C}$ doses and by Artés-Hernández et al. [33] on fresh-cut watermelon treated with $1.60,2.80,4.80$ and $7.20 \mathrm{~kJ} / \mathrm{m}^{2} \mathrm{UV}-\mathrm{C}$ doses.

In addition, these results with $\mathrm{O}_{3}$ treatments agreed with that of Ong et al. [18] who reported that the papaya fruit, when treated with concentrations of $\mathrm{O}_{3}$ lower than $5 \mu \mathrm{L} / \mathrm{L}$, presented slower RR with respect to the control. In the same way, Tzortzakis et al. [34] also reported that the RR of tomato fruits stored at $13^{\circ} \mathrm{C}$ did not suffered significant changes in atmospheres with low levels of ozone.

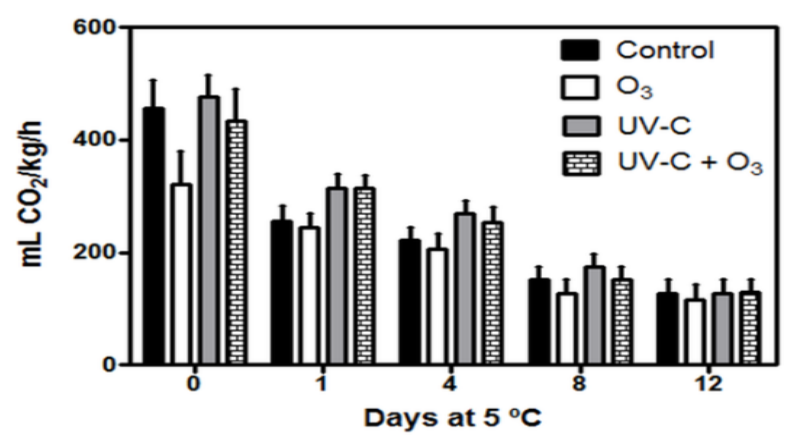

Figure 1. Respiration rate within packages of fresh-cut rocket leaves treated with $\mathrm{O}_{3}$ and UV-C, and their combination, during storage up to 12 days at $5^{\circ} \mathrm{C}$. Data represent mean values of three replicates $(\mathrm{n}=3 \pm \mathrm{SD})$ 
The changes that were registered of the partial pressures of the $\mathrm{O}_{2}$ and $\mathrm{CO}_{2}$ gases during storage inside the MAP packages are showed in Figure 2. Due to the respiratory activity of the vegetable, $\mathrm{O}_{2}$ levels decreased while those of $\mathrm{CO}_{2}$ increased both in the control and in the treatments [26,27]. From day-1 to day-12 storage, the partial pressures of the gases at equilibrium for all samples were $7-8 \mathrm{kPa} \mathrm{O}_{2}$ and $3-4 \mathrm{kPa} \mathrm{CO}_{2}$ at $5^{\circ} \mathrm{C}$.

During the first four days of storage at $5^{\circ} \mathrm{C}$, both UV-C and $\mathrm{UV}-\mathrm{C}+\mathrm{O}_{3}$ treatments registered higher $\mathrm{CO}_{2}$ levels with respect to the control sample and the $\mathrm{O}_{3}$ treatment. The different doses of UV-C radiation used could cause these differences in the results [8]. However, from day-8 until the end of storage no significant differences were found among the control and treated samples. These results agree with those observed in RR as significant differences are not observed for all the treatments at the end of the conservation period. These results indicated that the separate treatments with UV-C and $\mathrm{O}_{3}$ and that with both combined had no influence on the RR of fresh-cut rocket leaves.

These results with UV-C light coincide with those reported by Tomás-Callejas et al. [35], who reported that UV-C treatment $\left(4.54 \mathrm{~kJ} / \mathrm{m}^{2}\right)$ in fresh-cut Tatsoi baby leaves showed higher levels of $\mathrm{CO}_{2}$ and lower $\mathrm{O}_{2}$ through storage at $5^{\circ} \mathrm{C}$. Previous work also reported that treatment with $\mathrm{O}_{3}$ did not produce a higher $\mathrm{RR}$ with respect to chlorine treatments [26,36].

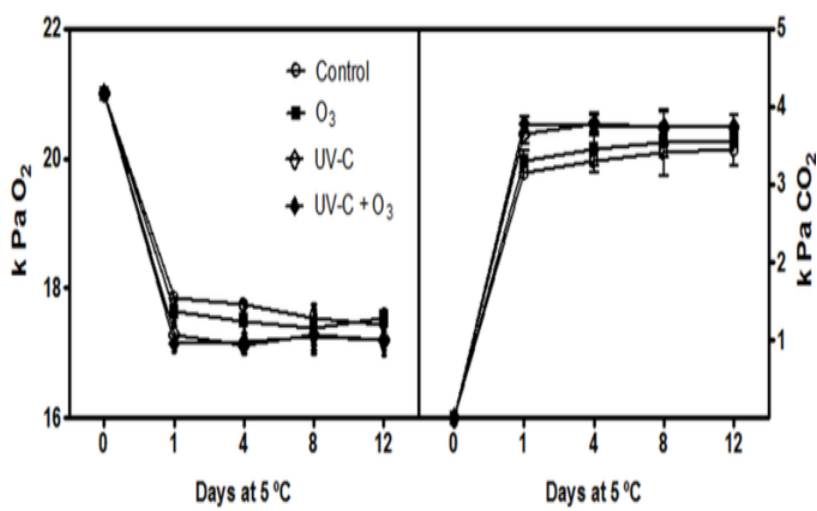

Figure 2. Gas changes within packages of fresh-cut rocket leaves treated with $\mathrm{O}_{3}$ and UV-C, and their combination, during storage up to 12 days at $5^{\circ} \mathrm{C}$. Data represent mean values of three replicates $(n=3 \pm S D)$

\subsection{Sensory Evaluation}

The products are accepted in the market if they satisfy the consumers, therefore it is vital to evaluate the sensory and organoleptic characteristics of the vegetables to which the practical innovations are applied [34, 37]. Their visual quality, color, and odor were the most affected sensory parameters during the 12 day storage at $5^{\circ} \mathrm{C}$. In all the treatments a decrease of these parameters was observed during the storage at $5^{\circ} \mathrm{C}$, although they did not present scores below the acceptability limit due to the fact that they did not present undesirable symptoms Table 1 . At the end of storage, only were significant differences found among the $\mathrm{O}_{3}$ and $\mathrm{UV}-\mathrm{C}+\mathrm{O}_{3}$ treated samples.

According to these results of the sensory evaluation, it could be concluded that the treatments with UV-C, $\mathrm{O}_{3}$ or the combination of both, did not affected the general sensory attributes of the fresh-cut rocket leaves during 12 days a $5^{\circ} \mathrm{C}$.

The results obtained in this work with $\mathrm{O}_{3}$ treatments agree with those of Ali et al. [37], who found that papaya fruits treated with different concentrations of $\mathrm{O}_{3}$ (2.5 and $3.5 \mathrm{mg} / \mathrm{L}$ ) showed high scores on sensory attributes after 12 days of storage at room temperature. Olmez and Akbas [36] also reported that lettuce treated with $\mathrm{O}_{3}$ showed better scores on sensory attributes with respect to washing with hypochlorite at day 9 .

In turn, the results obtained in this work using UV-C agree with Tomás-Callejas et al. [35] who found after 11 days of storage at $5^{\circ} \mathrm{C}$, a significant reduction in the overall sensory quality of baby leaves. On the other hand, Jemni et al. [38] reported that a combined treatment of $\mathrm{UV}-\mathrm{C}$ and $\mathrm{O}_{3}$ helped date fruits (cv. Deglet Nour) save good color after 30 days at $20^{\circ} \mathrm{C}$ with respect to the control.

Table 1. Visual quality score (A), color score (B) and odor score (C) of fresh-cut rocket leaves treated with $\mathrm{O}_{3}$ and $\mathrm{UV}-\mathrm{C}$, and their combination, during storage up to 12 days at $5^{\circ} \mathrm{C}$

\begin{tabular}{lcccc}
\hline \multirow{2}{*}{$\begin{array}{l}\text { Sensory parameter } \\
\text { and treatments }\end{array}$} & $\mathbf{4}$ & $\mathbf{4}$ & $\mathbf{8}$ & $\mathbf{1 2}$ \\
\cline { 2 - 5 } Visual quality score & & & \\
Control & $8.95 \mathrm{a}^{\mathrm{A}}$ & $8.50 \mathrm{a}^{\mathrm{B}}$ & $6.91 \mathrm{a}^{\mathrm{C}}$ & $6.52 \mathrm{a}^{\mathrm{D}}$ \\
$\mathrm{O}_{3}$ & $8.95 \mathrm{a}^{\mathrm{A}}$ & $8.60 \mathrm{a}^{\mathrm{B}}$ & $7.11 \mathrm{a}^{\mathrm{C}}$ & $6.65 \mathrm{a}^{\mathrm{D}}$ \\
UV-C & $8.80 \mathrm{a}^{\mathrm{A}}$ & $8.32 \mathrm{a}^{\mathrm{B}}$ & $6.77 \mathrm{a}^{\mathrm{C}}$ & $6.27 \mathrm{ab}^{\mathrm{D}}$ \\
UV-C $+\mathrm{O}_{3}$ & $8.97 \mathrm{a}^{\mathrm{A}}$ & $8.45 \mathrm{a}^{\mathrm{B}}$ & $6.72 \mathrm{a}^{\mathrm{C}}$ & $6.17 \mathrm{~b}^{\mathrm{D}}$ \\
Color score & & & & \\
Control & $4.95 \mathrm{a}^{\mathrm{A}}$ & $4.62 \mathrm{a}^{\mathrm{B}}$ & $3.80 \mathrm{a}^{\mathrm{C}}$ & $3.55 \mathrm{a}^{\mathrm{C}}$ \\
$\mathrm{O}_{3}$ & $4.95 \mathrm{a}^{\mathrm{A}}$ & $4.75 \mathrm{a}^{\mathrm{A}}$ & $3.90 \mathrm{a}^{\mathrm{B}}$ & $3.70 \mathrm{a}^{\mathrm{B}}$ \\
UV-C & $4.95 \mathrm{a}^{\mathrm{A}}$ & $4.55 \mathrm{a}^{\mathrm{B}}$ & $3.65 \mathrm{a}^{\mathrm{C}}$ & $3.42 \mathrm{a}^{\mathrm{C}}$ \\
UV-C $+\mathrm{O}_{3}$ & $4.95 \mathrm{a}^{\mathrm{A}}$ & $4.75 \mathrm{a}^{\mathrm{B}}$ & $3.67 \mathrm{a}^{\mathrm{C}}$ & $3.50 \mathrm{a}^{\mathrm{C}}$ \\
Odor score & & & & \\
Control & $4.95 \mathrm{a}^{\mathrm{A}}$ & $4.25 \mathrm{a}^{\mathrm{B}}$ & $3.80 \mathrm{a}^{\mathrm{C}}$ & $3.35 \mathrm{ab}^{\mathrm{D}}$ \\
$\mathrm{O}_{3}$ & $4.95 \mathrm{a}^{\mathrm{A}}$ & $4.40 \mathrm{a}^{\mathrm{B}}$ & $3.85 \mathrm{a}^{\mathrm{C}}$ & $3.45 \mathrm{a}^{\mathrm{C}}$ \\
UV-C & $4.95 \mathrm{a}^{\mathrm{A}}$ & $4.27 \mathrm{a}^{\mathrm{B}}$ & $3.67 \mathrm{a}^{\mathrm{C}}$ & $3.15 \mathrm{ab}^{\mathrm{D}}$ \\
UV-C $+\mathrm{O}_{3}$ & $4.95 \mathrm{a}^{\mathrm{A}}$ & $4.12 \mathrm{a}^{\mathrm{B}}$ & $3.55 \mathrm{a}^{\mathrm{C}}$ & $3.12 \mathrm{~b}^{\mathrm{D}}$ \\
\hline
\end{tabular}

Mean values in the same row with different superscript letters or in the same column for same type sample with different lowercase letters were significantly different according to LSD test at $\mathrm{P}<0.05$.

\subsection{Microbiological Profile}

To evaluate the efficacy of these treatments as to the initial reduction and microbial growth during storage at $5^{\circ} \mathrm{C}$ and to compare them to the traditional method that uses chlorine disinfection, a treatment with hipoclorite sodium $(\mathrm{NaClO})(100 \mathrm{mg} / \mathrm{L}, 2 \mathrm{~min})$ was included. Such a treatment is usually employed in the food industry.

The control samples showed an initial microbial load for total mesophilic aerobic bacteria (TMAB) of $5.7 \mathrm{log}$ $\mathrm{CFU} / \mathrm{g}$ Figure $3 \mathrm{~A}$. This count was reduced up to 0.8 and $1.1 \log \mathrm{CFU} / \mathrm{g}$ with the $\mathrm{NaClO}$ and $\mathrm{O}_{3}$ treatments, respectively. In turn, the $\mathrm{UV}-\mathrm{C}$ and the combined $\mathrm{UV}-\mathrm{C}+\mathrm{O}_{3}$ treatments were even more effective than the remainder since they reduced the load to 1.3 and $1.4 \mathrm{log}$ $\mathrm{CFU} / \mathrm{g}$ respectively, with respect to the control. The antimicrobial effect of the applied treatments was 
maintained during the first 8 days at $5^{\circ} \mathrm{C}$ compared to the control. However, on day-12, treatments with UV-C and $\mathrm{UV}-\mathrm{C}+\mathrm{O}_{3}$ showed higher reductions in TMAB with respect to the control and $\mathrm{O}_{3}$ treatment, and no significant differences between them were found.

The control samples showed an initial microbial load for psychrophilic counts of $6.1 \log \mathrm{CFU} / \mathrm{g}$ Figure $3 \mathrm{~B}$. The treatment with $\mathrm{NaClO}$ showed $0.92 \mathrm{log} \mathrm{CFU} / \mathrm{g}$ reduction while the $\mathrm{O}_{3}, \mathrm{UV}-\mathrm{C}$ and $\mathrm{UV}-\mathrm{C}+\mathrm{O}_{3}$ treatments led to reductions in the count of $1.20,1.37$ and $1.22 \mathrm{log} \mathrm{CFU} / \mathrm{g}$ respectively related to the control. The sanitizing treatments inhibited the psychrophilic growth in a similar way to the TAM counts, achieving a bacteriostatic effect during the first 8 days at $5^{\circ} \mathrm{C}$. However, at day 12 , contrary to TMAB counts, the $\mathrm{O}_{3}$ treatment presented the lowest psychrophilic count $(\mathrm{P}<0.05)$ compared to the control and the other treatments with no significant difference among them.

As to enterobacteria, the initial count was $4.7 \log$ $\mathrm{CFU} / \mathrm{g}$ Figure $3 \mathrm{C}$. The treatment with $\mathrm{NaClO}$ showed a reduction of the initial load of enterobacteria in $0.3 \mathrm{log}$ $\mathrm{CFU} / \mathrm{g}$ while the treatments $\mathrm{O}_{3}, \mathrm{UV}-\mathrm{C}$ and $\mathrm{UV}-\mathrm{C}+\mathrm{O}_{3}$ produced reductions ranging from 1.07 to $0.67 \mathrm{log} \mathrm{CFU} / \mathrm{g}$ in comparison with control. The antimicrobial effects of the sanitizing treatments lasted the first 8 days at $5^{\circ} \mathrm{C}$. However, at the end of storage, the UV-C treatment was the only maintaining the lowest count compared to the control and the other treatments.

Both mold and yeast were significantly inhibited by applying the sanitizing treatments though such effect was smaller than those produced upon bacteria Figure 3D. The $\mathrm{NaClO}$ and $\mathrm{O}_{3}$ treatments led to an initial reduction of molds and yeasts in approximately 0.34-0.59 $\log \mathrm{CFU} / \mathrm{g}$, respectively, compared to the control (5.09 log CFU/g). A stronger inhibitory effect occurred when the UV-C and $\mathrm{UV}-\mathrm{C}+\mathrm{O}_{3}$ treatments were applied since they showed reductions of 0.76 and $0.87 \mathrm{log} \mathrm{CFU} / \mathrm{g}$ respectively. At the end of storage, the UV-C, $\mathrm{O}_{3}$ and $\mathrm{UV}-\mathrm{C}+\mathrm{O}_{3}$ treatments kept the mold and yeast counts reductions compared to the control and $\mathrm{NaClO}$.

These results of the use of UV-C treatments agree with those of other vegetables in publications of other authors. Gogo et al. [14] reported that UV-C treatments $\left(1.7 \mathrm{~kJ} / \mathrm{m}^{2}\right)$ in amaranth leaves stored at $20^{\circ} \mathrm{C}$ significantly reduced the counts of mesophiles and yeasts after being applied, whereas in the mold counts, the control and UV-C treatments showed significant differences throughout the storage. Tomás-Callejas et al. [35] also reported that after being treated with UV-C, the microbial growth in Tatsoi baby-leaves was significantly reduced. In similar way, Martínez-Hernández et al. [39] reported that treatment with UV-C, reduced the initial microbial counts of broccoli and its effect was higher in the counts of mesophiles and yeast and molds.

The reduction in microbial counts observed in this work could be attributed to the germicidal effect of UV-C radiation causing denaturation of the DNA and/or the response of vegetable defense system to UV-C treatment $[14,40]$. In fresh-cut products it is being used as an alternative to conventional chlorine washes, UV-C radiation due to its germicidal effect [41].

With respect to the results with ozone, these agree with Olmez and Akbas [36] who found that treatments with $\mathrm{O}_{3}$
( 2 ppm-2 min) in lettuce caused a decrease in the counts of mesophiles, psychrotrophic and enterobacteria in approximately $1.5,1.1$ and $1.5 \log \mathrm{CFU} / \mathrm{g}$, respectively. Yeoh et al. [42] also reported that treatment with $\mathrm{O}_{3}$ $(9.2 \pm 0.2 \mu \mathrm{L} / \mathrm{L})$ during 10,20 and $30 \mathrm{~min}$ in fresh-cut papaya produced a reduction in the mesophilic count. In addition, Horvitz and Cantalejo [43] observed in fresh red peppers treated with $\mathrm{O}_{3}(0.7 \mathrm{mg} / \mathrm{L})$ during 1,3 and $5 \mathrm{~min}$ a reduction in the counts of yeasts, molds, mesophilic and psychrotrophic bacteria, while the treatment with $20 \mathrm{mg} / \mathrm{L}$ chlorinated water was not as effective.

On the other hand, Jemni et al. [38] found that date fruits treated with the combination of $0.55 \mathrm{mg} / \mathrm{L} \mathrm{O}_{3}+6.22$ $\mathrm{kJ} / \mathrm{m}^{2} \mathrm{UV}-\mathrm{C}$ produced the most effective reduction in the microbial load compared to that involving only $6.22 \mathrm{~kJ} / \mathrm{m}^{2}$ UV-C, which shows a synergistic effect between them. In some European countries, specific microbiological criteria have been adopted for minimally processed fruits and vegetables, such as Spain, where the legislation establishes that the maximum acceptable limit for the total viable count is $7 \log \mathrm{CFU} / \mathrm{g}$. It is worth mentioning that different research studies report on the antimicrobial effect of disinfectant treatments immediately after being applied, however it is also important to maintain this microbial reduction during storage.

In this work, the fresh-cut rocket leaves shelf-life was limited by the development of psychrophilic microorganisms. The microbial counts could be maintained below $7 \mathrm{log}$ $\mathrm{CFU} / \mathrm{g}$ up to day 8 of storage at $5^{\circ} \mathrm{C}$ with the separate and combined application of UV-C and $\mathrm{O}_{3}$ sanitizing treatments whereas shelf-life expectancy for control samples was lower than 6 days. In summary, the combined treatment $\mathrm{UV}-\mathrm{C}+\mathrm{O}_{3}$ did not produce a greater reduction of the microbial load with respect to the separate treatments of $\mathrm{UV}-\mathrm{C}$ and $\mathrm{O}_{3}$.

Therefore, with the application of the combined treatment of UV-C and $\mathrm{O}_{3}$, not synergistic or additive effect was observed with respect to the treatments applied separately.

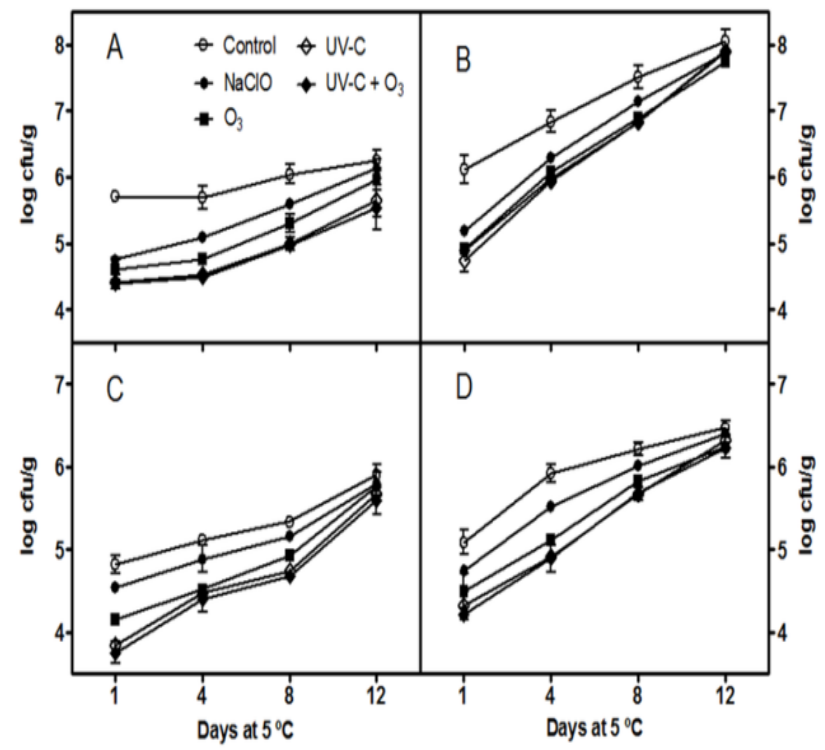

Figure 3. (A) Mesophilic, (B) psychrophilic, (C) enterobacteria and (D) mold and yeast counts $(\log \mathrm{CFU} / \mathrm{g}$ ) of fresh-cut rocket leaves treated with $\mathrm{O}_{3}$ and UV-C, and their combination, during storage up to 12 days at $5^{\circ} \mathrm{C}$. Data represent mean values of three replicates $(n=3 \pm \mathrm{SD})$ 


\subsection{Chlorophyll and Carotenoid Contents}

The initial total chlorophyll content was similar in all treatments, ranging from 92.5 to $98.7 \mathrm{mg} / 100 \mathrm{~g} \mathrm{fw}$ Table 2, with chlorophyll $a$ contributing with $72-78 \%$ of the total and chlorophyll $b$ with $28-22 \%$ to it (data not shown). Every treatment followed the same behavior concerning the total chlorophyll content throughout shelf-life at $5^{\circ} \mathrm{C}$; it decreased the first four days of storage and kept constant up to the end of storage. After 12 days, the total chlorophyll values were between 70.6 and 72.7 $\mathrm{mg} / 100 \mathrm{~g}$ fw, so they decreased by $24-27 \%$ of the initial values regardless the treatment applied, without significant differences between all the treatments. Gogo et al. [14] reported that UV-C radiation could cause a stress which would induce a decrease in the content of chlorophylls and carotenoids during storage. The data obtained in this work agreed with those reported by Tomás-Callejas et al. [35] who found that treatment with UV-C $\left(4.54 \mathrm{~kJ} / \mathrm{m}^{2}\right)$ in Tatsoi baby leaves did not cause any significant changes in the total chlorophyll content for 11 days at $5^{\circ} \mathrm{C}$. On the other hand, Gogo et al. [14] reported that vegetable amaranth and leaves of African

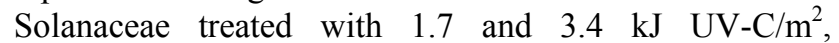
presented a decrease in the chlorophyll content until four days of storage at $5^{\circ} \mathrm{C}$.

Table 2. Total chlorophyll, total carotenoids, total polyphenols contents and total antioxidant activity changes of fresh-cut rocket leaves treated with $\mathrm{O}_{3}$ and $\mathrm{UV}-\mathrm{C}$, and their combination, during storage up to 12 days at $5^{\circ} \mathrm{C}$

\begin{tabular}{|c|c|c|c|c|}
\hline \multirow{2}{*}{$\begin{array}{l}\text { Bioactive compounds } \\
\text { and treatments }\end{array}$} & \multicolumn{4}{|c|}{ Days at $5^{\circ} \mathrm{C}$} \\
\hline & 1 & 4 & 8 & 12 \\
\hline \multicolumn{5}{|c|}{ Total chlorophyll (mg/100g fw) } \\
\hline Control & $93.6 \mathrm{ab}^{\mathrm{A}}$ & $80.6 \mathrm{ab}^{\mathrm{B}}$ & $70.7 \mathrm{a}^{\mathrm{C}}$ & $72.7 \mathrm{a}^{\mathrm{C}}$ \\
\hline $\mathrm{O}_{3}$ & $98.7 \mathrm{a}^{\mathrm{A}}$ & $82.4 \mathrm{a}^{\mathrm{B}}$ & $73.8 \mathrm{a}^{\mathrm{B}}$ & $72.3 \mathrm{a}^{\mathrm{B}}$ \\
\hline $\mathrm{UV}-\mathrm{C}$ & $93.2 \mathrm{ab}^{\mathrm{A}}$ & $76.2 \mathrm{ab}^{\mathrm{B}}$ & $69.5 \mathrm{a}^{\mathrm{B}}$ & $72.3 \mathrm{a}^{\mathrm{B}}$ \\
\hline $\mathrm{UV}-\mathrm{C}+\mathrm{O}_{3}$ & $92.5 \mathrm{ab}^{\mathrm{A}}$ & $72.1 \mathrm{~b}^{\mathrm{B}}$ & $71.0 \mathrm{a}^{\mathrm{B}}$ & $70.6 \mathrm{a}^{\mathrm{B}}$ \\
\hline \multicolumn{5}{|c|}{ Total carotenoids $(\mathrm{mg} / \mathbf{1 0 0 g} \mathrm{fw})$} \\
\hline Control & $21.4 \mathrm{a}^{\mathrm{A}}$ & $16.1 \mathrm{a}^{\mathrm{B}}$ & $17.7 \mathrm{a}^{\mathrm{AB}}$ & $14.6 \mathrm{a}^{\mathrm{B}}$ \\
\hline $\mathrm{O}_{3}$ & $21.6 \mathrm{a}^{\mathrm{A}}$ & $16.9 \mathrm{a}^{\mathrm{A}}$ & $17.9 \mathrm{a}^{\mathrm{A}}$ & $18.2 \mathrm{a}^{\mathrm{A}}$ \\
\hline $\mathrm{UV}-\mathrm{C}$ & $20.2 \mathrm{ab}^{\mathrm{A}}$ & $17.1 \mathrm{a}^{\mathrm{A}}$ & $17.3 \mathrm{a}^{\mathrm{A}}$ & $17.1 \mathrm{a}^{\mathrm{A}}$ \\
\hline $\mathrm{UV}-\mathrm{C}+\mathrm{O}_{3}$ & $21.0 \mathrm{ab}^{\mathrm{A}}$ & $16.3 \mathrm{a}^{\mathrm{A}}$ & $17.1 \mathrm{a}^{\mathrm{A}}$ & $15.7 \mathrm{a}^{\mathrm{B}}$ \\
\hline \multicolumn{5}{|c|}{ Total polyphenols content (mg ChAE/g fw) } \\
\hline Control & $1.8 \mathrm{a}^{\mathrm{A}}$ & $1.9 \mathrm{a}^{\mathrm{A}}$ & $1.9 \mathrm{a}^{\mathrm{A}}$ & $1.9 \mathrm{a}^{\mathrm{A}}$ \\
\hline $\mathrm{O}_{3}$ & $1.8 \mathrm{a}^{\mathrm{A}}$ & $1.9 \mathrm{a}^{\mathrm{A}}$ & $1.9 \mathrm{a}^{\mathrm{A}}$ & $1.8 \mathrm{a}^{\mathrm{A}}$ \\
\hline $\mathrm{UV}-\mathrm{C}$ & $1.9 \mathrm{a}^{\mathrm{A}}$ & $1.9 \mathrm{a}^{\mathrm{A}}$ & $1.9 \mathrm{a}^{\mathrm{A}}$ & $1.8 \mathrm{a}^{\mathrm{A}}$ \\
\hline $\mathrm{UV}-\mathrm{C}+\mathrm{O}_{3}$ & $1.8 \mathrm{a}^{\mathrm{A}}$ & $2.0 \mathrm{a}^{\mathrm{A}}$ & $1.9 \mathrm{a}^{\mathrm{A}}$ & $1.8 \mathrm{a}^{\mathrm{A}}$ \\
\hline \multicolumn{5}{|c|}{ Total antioxidant capacity (mg TE/g fw) } \\
\hline Control & $2.4 \mathrm{a}^{\mathrm{A}}$ & $2.4 \mathrm{a}^{\mathrm{A}}$ & $2.5 \mathrm{a}^{\mathrm{A}}$ & $2.6 \mathrm{a}^{\mathrm{A}}$ \\
\hline $\mathrm{O}_{3}$ & $2.5 \mathrm{a}^{\mathrm{A}}$ & $2.4 \mathrm{a}^{\mathrm{A}}$ & $2.5 \mathrm{a}^{\mathrm{A}}$ & $2.5 \mathrm{a}^{\mathrm{A}}$ \\
\hline $\mathrm{UV}-\mathrm{C}$ & $2.5 \mathrm{a}^{\mathrm{A}}$ & $2.4 \mathrm{a}^{\mathrm{A}}$ & $2.4 \mathrm{a}^{\mathrm{A}}$ & $2.5 \mathrm{a}^{\mathrm{A}}$ \\
\hline $\mathrm{UV}-\mathrm{C}+\mathrm{O}_{3}$ & $2.5 \mathrm{a}^{\mathrm{A}}$ & $2.5 \mathrm{a}^{\mathrm{A}}$ & $2.5 \mathrm{a}^{\mathrm{A}}$ & $2.5 \mathrm{a}^{\mathrm{A}}$ \\
\hline
\end{tabular}

Mean values in the same row with different superscript letters or in the same column for same type sample with different lowercase letters were significantly different according to LSD test at $\mathrm{P}<0.05$.

As to ozone, the results of this work agree with those of Karaca and Velioglu [20] who found that the content of chlorophyll was not modified in parsley treated with gaseous $\mathrm{O}_{3}$ at a concentration of $950 \pm 12 \mu \mathrm{L} / \mathrm{L}$ for $20 \mathrm{~min}$. Notwithstanding, Olmez and Akbas [36] reported that ozone treatments caused discoloration in lettuce after being treated.
The initial total carotenoids content in fresh-cut rocket leaves was similar in all treatments, ranging from 20.2 to $21.6 \mathrm{mg} / 100 \mathrm{~g}$ fw Table 2 . Along storage at $5^{\circ} \mathrm{C}$, with the exception of the control and UV-C $+\mathrm{O}_{3}$ treatments that showed decreases of 32 and $26 \%$, respectively as to their initial value, the total content of carotenoids remained constant. However, non-significant differences were found either among treatments or they respect to the control. Gogo et al. [14] found that UV-C treatments with doses of 1.7 and $3.4 \mathrm{~kJ} / \mathrm{m}^{2}$ in vegetable amaranth and African Solanaceae leaves caused a decrease in the total carotenoid content during the first 4 days of storage at $5^{\circ} \mathrm{C}$. Different authors suggested that the treatments with UV-C radiation synthesize and degrade (photooxidation) the content of chlorophylls and carotenoids $[14,44]$.

On the other hand, the results obtained with ozone agree with those reported by Tzortzakis et al. [34], who reported that the content of carotenoids (beta carotene, lutein and lycopene) were not affected by treatments with $\mathrm{O}_{3}$ in tomato fruits.

\subsection{Total Phenolic Content}

The initial total phenolic content was similar in all the treatments, ranging between 1.8 and $1.9 \mathrm{mg} \mathrm{ChAE} / \mathrm{g}$ fw Table 2. During the shelf life at $5^{\circ} \mathrm{C}$, the phenolic content remained constant in all treatments, with no differences between the control and the treated samples.

These results agree with those reported by Jemni et al. [38], who reported that date fruits (cv. Deglet Nour) immediately after treated with $2.37 ; 6.22 ; 8.29$ and $12.14 \mathrm{~kJ} / \mathrm{m}^{2} \mathrm{UV}-\mathrm{C}$ and $0.55 \mathrm{mg} / \mathrm{L} \mathrm{O}_{3}+6.22 \mathrm{~kJ} / \mathrm{m}^{2} \mathrm{UV}-\mathrm{C}$, did not show significant differences in the phenolic content compared to the control. However, they reported a slight increase in their phenolic content through storage at $20^{\circ} \mathrm{C}$, particularly in the control and samples treated with $\mathrm{UV}-\mathrm{C}+\mathrm{O}_{3}$. Based on the above, they concluded that the phenolic compounds are stabilized by UV-C radiation. Despite this, UV-C treatments can also be effective to increase the phenolic contents of vegetables [35]. For example, it was reported that UV-C treatments increase the phenolic compounds in wine grapes [45], watermelon [33], Tatsoi baby leaves [35], minimally processed yam slices $[1,46]$ and minimally processed lily bulb [2].

This finding related to ozone treatment agrees with the results obtained by Glowacz and Rees [47], who reported that green peppers exposed to different concentrations of $\mathrm{O}_{3}(0.45,0.9$ and $2 \mu \mathrm{mol} / \mathrm{mol})$ were not affected in the total phenolic content. Likewise, Glowacz et al. [48] found no significant differences between untreated red peppers and those treated with ozone at concentrations of 0.1 and $0.3 \mu \mathrm{mol} / \mathrm{mol}$.

\subsection{Antioxidant Capacity}

The initial total antioxidant activity was similar in all the treatments, ranging from 2.4 and $2.5 \mathrm{mg} \mathrm{TE} / \mathrm{g}$ fw. As it can be observed for the total phenolic content, the total antioxidant capacity maintained constant through storage in every treatment showing no differences among them Table 2. These results with UV-C radiation agreed with that reported by Jemni et al. [38], who informed that the 
total antioxidant activity of Deglet Nour cv. was stabilized with UV-C treatments during storage at $20^{\circ} \mathrm{C}$. Jin et al. [49] maintain that the total phenolic content is related to the antioxidant capacity.

In contrast, Tomás-Callejas et al. [35] reported that UV-C treatments $\left(4.54 \mathrm{~kJ} / \mathrm{m}^{2}\right)$ in Tatsoi baby leaves significantly increased the total phenolic content and total antioxidant capacity throughout the first four days of storage at $5^{\circ} \mathrm{C}$. Huang et al. [2] also reported that UV-C treatments caused an improvement of antioxidant capacity in minimally processed bulbs, due to an increase in total phenolic content. In addition, similar results were observed in the antioxidant activity of mushrooms treated with UV-C [50].

The results of the present work with ozone agree with those obtained by Glowacz and Rees [47] who observed that treatments with $\mathrm{O}_{3}(0.45,0.9$ and $2 \mu \mathrm{mol} / \mathrm{mol})$ in red chili peppers did not affect their antioxidant capacity. Similarly, Tzortzakis et al. [34] also reported that treatments with $\mathrm{O}_{3}(1 \mu \mathrm{mol} / \mathrm{mol})$ in tomatoes, did not cause changes in the antioxidant activity of the same for 6 days.

\section{Conclusions}

The development of psychrophilic microorganisms limited the shelf-life of the fresh-cut rocket leaves until 8 days at $5^{\circ} \mathrm{C}$ for all the treatments applied. The separate UV-C or $\mathrm{O}_{3}$ treatments or both combined showed better effect than the traditional washing with $\mathrm{NaClO}$ in controlling psychrophilic growth. In addition, these treatments did not affect the bioactive compounds or their main quality attributes during storage at $5^{\circ} \mathrm{C}$.

The application of these treatments could be useful tools for disinfection of fresh-cut rocket leaves, maintaining their general quality and prolonging their shelf life. The application of the combined treatment of UV-C and $\mathrm{O}_{3}$ did not produce a synergistic or additive effect with respect to the treatments applied separately. Therefore, taking into account the costs and processing times at an industrial level, it would be appropriate to apply treatment with $25 \mathrm{~kJ} \mathrm{UV-C} / \mathrm{m}^{2}$.

\section{Acknowledgments}

Special thanks to ICyTA-FAyA-UNSE, CICyT-UNSE, PICTO-UNSE project (12-00007) and CONICET which finances Dr. Gutierrez's training grant.

\section{References}

[1] Teoh L. S., Lasekan O., Adzahan N. M., and Hashim N. (2016) The effect of combinations of UV-C exposure with ascorbate and calcium chloride dips on the enzymatic activities and total phenolic content of minimally processed yam slices. Postharvest Biology and Technology, 120: 138-144.

[2] Huang H., Ge Z., Limwachiranon J., Li L., Li W., and Luo Z. (2017). UV-C treatment affects browning and starch metabolism of minimally processed lily bulb. Postharvest Biology and Technology, 128: 105-111.

[3] Cocetta G., Baldassarre V., Spinardi A., and Ferrante A. (2014). Effect of cutting on ascorbic acid oxidation and recycling in fresh-cut baby spinach (Spinacia oleracea L.) leaves. Postharvest Biology and Technology, 88: 8-16.

[4] Char C., Silveira A.C., Inestroza-Lizardo C., Hinojosa A., Machuca A., and Escalona V. H. (2012). Effect of noble gas-enriched atmospheres on the overall quality of ready-to-eat arugula salads. Postharvest Biology and Technology, 73: 50-55.

[5] Manchali S., Chidambara Murthy K.N., and Patil B.S. (2012). Crucial facts about health benefits of popular cruciferous vegetables. Journal of Functional Foods, 4: 94-106.

[6] Oliveira M., Abadias M., Usall J., Torres R., Teixidó N., and Viñas I. (2015). Application of modified atmosphere packaging as a safety approach to fresh-cut fruits and vegetables-A review. Trends Food Science Technology, 46: 13-26.

[7] Hinojosa A., Gatica I., Bustamante A., Cárdenas D., and Escalona V. (2015). Effect of the combined treatment of UV-C light and modified atmosphere packaging on the inactivation of Escherichia coli inoculated watercress. Journal Food Processing and Preservation, 39: 1525-1533.

[8] Lu Y., Zhang J., Wang X., Lin Q., Liu W., Xie X., Wang Z., and Guan W. (2016). Effects of UV-C irradiation on the physiological and antioxidant responses of button mushrooms (Agaricus bisporus) during storage. International Journal Food Science and Technology, 51: 1502-1508.

[9] Rodoni L.M., Concellón A.I., Chaves A.R., and Vicente A.R. (2012). Use of UV-C treatments to maintain quality and extend the shelf life of green fresh-cut bell pepper (Capsicum аппиит L.). Journal of Food Science, 77: 632-639.

[10] Choi I.L., Yoo T.J., and Kang H.M. (2015). UV-C treatments enhance antioxidant activity, retain quality and microbial safety of fresh-cut paprika in MA Storage. Hortic Environ Biotechnology, 56: 324-329.

[11] George D.S., Razali Z., Santhirasegaram V., and Somasundram C. (2015). Effects of ultraviolet light (UV-C) and heat treatment on the quality of fresh-cut Chokanan mango and Josephine pineapple. Journal of Food Science, 80: 426-434.

[12] Cetin E.S. (2014). Induction of secondary metabolite production by UV-C radiation in Vitis vinifera L. Öküzgözü callus cultures. Biological Research, 47: 1-7.

[13] Tarek A.R., Rasco B.A., and Sablani S.S. (2016). Ultraviolet-C light sanitization of English cucumber (Cucumis sativus) packaged in polyethylene film. Journal of Food Science, 81: 1419-1430.

[14] Gogo E.O., Opiyo A.M., Hassenberg K., Ulrichs C., and Huyskens-Keil S. (2017). Postharvest UV-C treatment for extending shelf life and improving nutritional quality of African indigenous leafy vegetables. Postharvest Biology and Technology, 129: $107-117$

[15] Jagadeesh S.L., Charles M.T., Gariepy Y., Goyette B., Raghavan G.S., and Vigneault C. (2011). Influence of postharvest UV-C hormesis on the bioactive components of tomato during post-treatment handling. Food Bioprocess Technology, 4: 1463-1472.

[16] Bravo S., García-Alonso J., Martín-Pozuelo G., Gómez V., Santaella M., and Navarro-González I. (2012). The influence of post-harvest UV-C hormesis nolycopene-carotene, and phenolic content and antioxidant activity of breaker tomatoes. Food Research International, 49: 296-302.

[17] Park M.H., and Kim J.G. (2015). Low-dose UV-C irradiation reduces the microbial population and preserves antioxidant levels in peeled garlic (Allium sativum L.) during storage. Postharvest Biology and Technology, 100: 109-112.

[18] Ong M.K., Ali A., Alderson P.G., and Forney C.F. (2014). Effect of different concentrations of ozone on physiological changes associated to gas exchange, fruit ripening, fruit surface quality and defense-related enzymes levels in papaya fruit during ambient storage. Scientia Horticulturae, 179: 163-169.

[19] US-FDA, United States Food and Drug Administration. (2001). "Secondary direct food additives permitted in food for human consumption. Federal Register, Rules and Regulations, June 26, Volume: 66, Number: 123, Sec., 173.368 Ozone, Final Rule.

[20] Karaca H., and Velioglu Y.S. (2014). Effects of ozone treatments on microbial quality and some chemical properties of lettuce, spinach, and parsley. Postharvest Biology and Technology, 88: 46-53.

[21] Minas I.S., Karaoglanidis G.S., Manganaris G.A., and Vasilakakis M. (2010). Effect of ozone application during cold storage of kiwifruit on the development of stem-end rot caused by Botrytis cinerea. Postharvest Biology and Technology, 58(3): 203-210. 
[22] Botondi R., Moscetti R., and Massantini R. (2016). A comparative study on the effectiveness of ozonated water and peracetic acid in the storability of packaged fresh-cut melon. Journal Food Processing and Preservation, 53: 2352-2360.

[23] Liu C., Ma T., Hu W., Tian M., and Sun L. (2016). Effects of aqueous ozone treatments on microbial load reduction and shelf life extension of fresh-cut apple. International Journal Food Science and Technology, 51: 1099-1109.

[24] Alothman M., Kaur B., Fazilah A., Bhat R., and. Karim A.A. (2010). Ozone-induced changes of antioxidant capacity of freshcut tropical fruits. Innovative Food Science and Emerging Technology, 11: 666-671.

[25] Sachadyn-Król M., Materska M., Chilczuk B., Karaś M., Jakubczyk A., Perucka I., and Jackowska I. (2016). Ozone-induced changes in the content of bioactive compounds and enzyme activity during storage of pepper fruits. Food Chemistry, 211: 59-67.

[26] Gutiérrez D.R., Chaves A.R., and Rodriguez S.C. (2016). Use of UV-C and gaseous ozone as sanitizing agents for keeping the quality of fresh-cut rocket (Eruca sativa Mill.). Journal Food Processing and Preservation, 00: 1-13.

[27] Martínez-Hernández G.B., Artés-Hernández F., Gómez P.A., Formica A.C., and Artés F. (2013). Combination of electrolysed water, UV-C and superatmospheric $\mathrm{O}_{2}$ packaging for improving fresh-cut broccoli quality. Postharvest Biology and Technology, 76: $125-134$.

[28] Gutiérrez D.R., and Rodríguez S.C. (2017). Combined effect of UV-C and modified atmosphere packaging for keeping antioxidant compounds and extend to shelf-life of fresh-cut rocket leaves. International Journal of New Technology and Research (IJNTR), 03: 62-68.

[29] Gutiérrez D.R., Char C., Escalona V.H., Chaves A.R., and. Rodríguez S.C. (2015). Application of UV-C radiation in the conservation of minimally processed rocket (Eruca sativa Mill.). Journal Food Processing and Preservation, 39(6): 3117-3127.

[30] Lichtenthaler H.K. (1987). Chlorophylls and carotenoids: pigments of photosynthetic biomembranes. Methods Enzymology, 148: 350-382.

[31] Singleton V.L., Orthofer R., and Lamuela-Raventós R.M. (1999). Analysis of total phenols and other oxidation substrates and antioxidants by means of Folin-Ciocalteau reagent. Method Enzymology, 299:152-153.

[32] Brand-Williams W., Cuvelier M.E., and Berset C. (1995). Use of the free radical method to evaluate antioxidant activity. LWT-Food Science Technology, 28: 25-30.

[33] Artés-Hernández F., Robles P.A., Gómez P.A., Tomás-Callejas A., and Artés F. (2010). Low UV-C illumination for keeping overall quality of fresh-cut watermelon. Postharvest Biology and Technology, 55: 114-120.

[34] Tzortzakis N., Borland A., Singleton I., and Barnes J. (2007) Impact of atmospheric ozone-enrichment on quality-related attributes of tomato fruit. Postharvest Biology and Technology, 45: $317-325$.

[35] Tomás-Callejas A., Otón M., Artés F., and Artés-Hernández F. (2012). Combined effect of UV-C pretreatment and high oxygen packaging for keeping the quality of fresh-cut Tatsoi baby leaves. Innovative Food Science Emerging Technology, 14: 115-121.
[36] Olmez H., and Akbas M.Y. (2009). Optimization of ozone treatment of fresh-cut green leaf lettuce. Journal of Food Engineering, 90: 487-494.

[37] Ali A., Ong M.K., and Forney C.F. (2014) Effect of ozone pre-conditioning on quality and antioxidant capacity of papaya fruit during ambient storage. Food Chemistry, 142: 19-26.

[38] Jemni M., Gómez P.A., Souza M., Chaira N., Ferchichi A., Otón M., and Artés, F. (2014). Combined effect of UV-C, ozone and electrolyzed water for keeping overall quality of date palm. LWT-Food Science Technology, 59(2): 649-655,

[39] Martínez-Hernández G.B., Gómez P.A., Pradas I., Artés F., and Artés-Hernández F. (2011). Moderate UV-C pretreatment as a quality enhancement tool in fresh-cut Bimi broccoli. Postharvest Biology and Technology, 62: 327-337.

[40] Manzocco L., Da Pieve S., and Maifreni M. (2011). Impact of $\mathrm{UV}-\mathrm{C}$ light on safety and quality of fresh-cut melon. Innovative Food Science Emerging Technology, 12: 13-17.

[41] Martínez-Hernández G. B., Navarro-Rico J., Gómez P.A., Otón M., Artés F., and Artés-Hernández F. (2015). Combined sustainable sanitising treatments to reduce Escherichia coli and Salmonella enteritidis growth on fresh-cut kailan-hybrid broccoli. Food Control, 47: 312-317.

[42] Yeoh W.K., Ali A., and Forney C.F. (2014). Effects of ozone on major antioxidants and microbial populations of fresh-cut papaya. Postharvest Biology and Technology, 89: 56-58

[43] Horvitz S., and Cantalejo M.J. (2008). The effects of gaseous ozone and chlorine on quality and shelf life of minimally processed red pepper. ISHS Acta Horticulturae, 877: 583-589.

[44] Cazzaniga S., Bressan M., Carbonera D., Agostini A., and Dall'Osto L. (2016). Differential roles of carotenes and xanthophylls in photosystem I photoprotection. Biochemistry, 55: 3636-3649.

[45] Guerrero R. F., Puertas B., Jiménez M. J., Cacho J., and Cantos-Villar E. (2010). Monitoring the process to obtain red wine enriched in resveratrol and piceatannol without quality loss. Food Chemistry, 122: 195-202.

[46] Li S.T., Lasekan O., Adzahan N.M., and Hashim N. (2016). The effect of combinations of UV-C exposure with ascorbate and calcium chloride dips on the enzymatic activities and total phenolic content of minimally processed yam slices. Postharvest Biology and Technology, 120: 138-144.

[47] Glowacz M., and Rees D. (2016). Exposure to ozone reduces postharvest quality loss in red and green chilli peppers. Food Chemistry, 210: 305-310.

[48] Glowacz M., Colgan R., and Rees D. (2015). Influence of continuous exposure to gaseous ozone on the quality of red bell peppers, cucumbers and zucchini. Postharvest Biology and Technology, 99: 1-8.

[49] Jin P., Yao D., Xu F., Wang H., and Zheng Y. (2015). Effect of light on quality and bioactive compounds in postharvest broccoli florets. Food Chemistry, 172: 705-709.

[50] Wu X., Guan W., Yan R., Lei J., Xu L., and Wang Z. (2016). Effects of UV-C on antioxidant activity, total phenolics and main phenolic compounds of the melanin biosynthesis pathway in different tissues of button mushroom. Postharvest Biology and Technology, 118: 51-58. 